\title{
When Development Is Not Universal: Understanding the Unique Developmental Tasks that Race, Gender, and Social Class Impose
}

\author{
Commentary on Rogers and Way \\ Na'ilah Suad Nasir \\ UC Berkeley, Berkeley, CA, USA; Spencer Foundation, Chicago, IL, USA
}

\section{Keywords}

Adolescent development $\cdot$ Nondominant students $\cdot$ Identity development $\cdot$ Race

I read Reimagining social and emotional development: Accommodation and resistance to cultural ideologies in identities and friendships of boys of color by Leoandra Onnie Rogers and Niobe Way with great interest. I highly respect the work of both of these scholars, and I have written several papers about the salience of race in the identity development process [Cvencek, Nasir, O'Connor, \& Meltzoff, 2014; Nasir, Snyder, Shah, \& Ross, 2012]. However, where my own scholarship has focused on the challenges to young people's identities when they are stereotyped by race, which limits the possibilities for who they can be and become, this important article focuses on how young people, boys of color specifically, resist the dominant gendered and raced ideologies that seek to constrict their expressions of friendship and emotion.

The article emphasizes the bidirectionality of developmental processes, taking as a premise that individual development occurs in relation to the cultural context, and that development both responds to and shapes that context [Bronfenbrenner, 1983; Cole, 1996; Gutiérrez \& Rogoff, 2003; Rogoff, 2003]. But the article goes a step further than that. It argues that not only is development culturally situated, it is also socially and politically situated. In other words, development - emotional, social, cognitive - is always in interaction with the constraints and affordances of the society that surrounds it. That includes interactions shaped by societies' key institutions, social categories, and ideologies. And given that we are in a society that is highly structured by race and social class [Carter, 2012], this observation is central for accurately accounting for the development of both students from nondominant groups and students from dominant groups (whose lives are equally and differentially shaped by race and social class).

KARGER @ 2018 S. Karger AG, Basel
$\begin{aligned} & \text { E-Mail karger@karger.com } \\ & \text { www.karger.com/hde }\end{aligned}$


I find it to be a powerful contribution to assert that young people from marginalized groups must navigate the complexities of when to accommodate dominant ideologies and when to resist them, and that the resistance is central to healthy development. This theoretical insight may be even more important in a social and political time where the social narratives and stereotypes are being deployed in symbolically violent ways in the media and elsewhere.

The focus on boys of color is also quite important - too often they are missing in the developmental literature and invisible with respect to their emotional life. Others have noted the ways in which emotion is contested territory for boys of color [Johnson, Pate, \& Givens, 2010]. This article moves us in a courageous direction by centering the situated developmental processes of boys of color, recognizing the role of power and social position in these developmental processes, and seeing these young men and boys of color as active agents in their own development. Importantly, expressing emotion can be such an act of agency.

The article sparked my thinking in a number of directions. Here I offer four key questions that were raised for me by this piece.

\section{Question 1: How and Where Do Young People Learn to Resist?}

We see in the article powerful examples of young men and boys of color resisting the dominant gendered and raced narratives about themselves by disregarding social norms around male friendships not being closely bonded, and around males not expressing emotion toward one another. These examples are rich in detail and poignant. As I read them I wondered, however, where do these young people learn to resist? From whom do they learn that such disregard of stereotypes or of social norms is possible? Where do they see examples of men who illustrate for them another way to be?

These questions are, on the one hand, a pondering on the processes that were not studied, about the environments and social relationships that underlie the types of exchanges we saw in the data presented. But there is something more at stake here - I am also asking that we make visible the kinds of supports that young people draw upon that too often go unseen, and thus get chalked up to individual differences. My own data [Nasir, 2012] suggest that racial socialization conversations rarely happen in schools but are more common among family members or in community or afterschool settings. Anecdotally, I have some sense that where you find young people able to resist societal narratives about themselves and/or groups they belong to, it is most often attributable to conversations that they are having with key adult others, perhaps a parent, uncle, or community member. We need to know more about what these conversations look like, how they unfold, and how they take shape in relation to developmental demands. In short, it is key that we begin to understand the importance and role of the multiple local developmental settings that young people participate in, and their relationships with others in those settings.

The authors write: "Dominant ideologies, thereby, organize what it means to be a Black boy, a working-class teenager, or an Asian, middle-class, girl ...” This is a key assertion which is profound in its implications. Because if what it means to be who you are is defined by dominant ideologies, and those ideologies relegate you to a stereotype, how do young people choose to be something different than that? This is a 
critically important question to answer with a developmental lens, because if young people do not figure out how to choose to be something other than the stereotypes about their groups, they will never develop their full potential. Further, as a society, we will continue to reproduce problematic, systematic differences in school achievement, in college going rates, in representation in critical areas like STEM and the arts.

\section{Question 2: How Do Social Media Spaces Impact the Capacity for Resistance?}

As we consider the range of ways young people learn to resist, it seems critically important to pay some attention to the myriad of social media spaces that young people frequent. I am thinking specifically around recent scholarship in media studies around Black Twitter [Hill, 2018] that has argued that social media spaces can provide access to counternarratives that reshape how participants think and talk about issues of race and gender. This work has also shown that the kinds of interactions that occur on social media spaces like Twitter around issues of race and gender can serve as critical teaching spaces, where individuals are "called in" for problematic or insensitive comments and offered new conceptualizations and terminology.

This line of work highlights the possibility of social media spaces to help young people learn about difference, and to find a space to develop critical literacy. However, some have argued that social media can exacerbate a kind of social siloing [Tartaglione, 2017], whereby people exist in a bubble of those like them, and are less and less likely to be exposed to perspectives different from their own. In any case, I think this question warrants some empirical attention, as most certainly these social media spaces are developmental contexts whereby young people's identities are being shaped in new ways, and where they may be developing the capacity for resistance.

\section{Question 3: How Do We Understand the Emotional Work this Resistance Entails?}

As I read the examples in the data of how the boys of color that Rogers and Way studied navigated the resistance of key norms about race and about gender, it occurred to me that such resistance requires a lot of emotional work. Consider the student, Marcus, who talks about the way that others impose stereotypes upon him to be "violent" and to have multiple women. He identifies a goal of his: to "prove all of these people wrong." It struck me in reading this that Marcus is shouldering quite an emotional burden as he navigates the process both of being stereotyped and of proving those around him as wrong through his behavior and achievement. Marcus is taking on acting for and representing an entire racial and gender group. We know from Goleman's [1995] work on emotional intelligence that managing your own emotions and managing the reactions of others is a challenging task.

Later in the text Marcus admits that in fact, being stereotyped makes him quite angry, and he has to find ways not to show this anger. What is required developmentally for a young person like Marcus to be managing such basic emotional reactions in a world where the consequences for not doing so effectively can be dire? They must manage their own emotions as well as the reactions and expectations of others. What 
I am trying to point out is that these processes of resisting dominant narratives are not developmentally neutral in the distribution of burdens: the boys of color in these studies are simply having to do more than students who do not have to do the work of deciding if and how to resist.

My colleagues and I studied an all-Black, all-male manhood development class in a large urban district (Nasir, Givens, \& Chatmon, 2019, submitted). These classes met daily and were taught by Black male instructors. In one class session that we observed an instructor was speaking to a high school student who walked into class with his hoodie pulled up over his head. The instructor politely asked the young man to take it off, saying to him, "you are safe here." This assertion of safety in the manhood development class was also a recognition of the lack of safety in the school and in other parts of society. What I think is interesting in relation to the argument Rogers and Way are making is that the lack of safety has consequences, even if managed well by students who find a way to resist. We must more deeply understand and study the costs of resistance and of accommodation.

\section{Question 4: How Do We Design Spaces for the Development of Resistance?}

As I've noted, I think it is critical that we more deeply understand how we can better support young people, and boys of color in particular, in navigating this balance of accommodation and resistance to dominant ideologies. Too much accommodation, and damage can be done to a healthy sense of self; unqualified resistance, and every minute of every day can be a battle. It is one thing to recognize and describe important instances of healthy resistance to dominant ideologies, but it is another thing entirely to figure out how to support it in our design of learning environments for young people.

So that leaves an open question: how might we design spaces and provide access to interactions that minimize the burdens on individual students to have to figure out how to do this complex work on their own? We do know some things from the existing literature. Steele's work on identity safe classrooms [Steele \& Cohn-Vargas, 2013] points out that it is critical for classroom environments to support the full range of the identities students bring into the classroom, and it highlights key characteristics of these classrooms, including being spaces where students' sense of belonging is attended to. Ross' work on Black space [Ross, 2016, in press] illustrates the powerful possibility in spaces set aside for same-race, same-gender groups to provide healing experiences for the race- and gender-related trauma that young people experience. My own work would suggest that spaces where young people can be themselves, where they can make authentic contributions to the learning activity, and where they are assumed to be competent are critically important [Nasir, 2012]. However, there is more we need to learn. What structures in classrooms and out-of-school settings support the development of the kind of emotional management that young people need? What types of interactions afford or constrain this development? How should experiences be organized for young people in accordance with their developmental stages and needs?

The question of how to design learning environments to best support the demands that dominant stereotypical narratives place on young people is one that we must take seriously, and it points to the importance of drawing connections between 
the developmental literature and the learning science literature. This research also raises the question of how we think about and account for the influence of multiple kinds of learning spaces (schools, homes, extended families, afterschool programs, community settings) on the developmental capacities of young people. There is certainly much to ponder here, and Rogers and Way have opened a dialogue that I think is critical for us to take up as a field.

\section{References}

Bronfenbrenner, U. (1983). The context of development and the development of context. In R. Lerner (Ed.), Developmental Psychology: Historical and philosophical perspectives. Hillsdale, NJ: Erlbaum.

Carter, P. (2012). Stubborn Roots: Race, culture, and inequality in U.S. and South African schools. Oxford, UK: Oxford University Press. doi.org/10.1093/acprof:oso/9780199899630.001.0001

Cole, M. (1996). Cultural psychology: A once and future discipline. Cambridge, MA: Harvard University Press.

Cvencek, D., Nasir, N., O’Connor, S., \& Meltzoff, A. (2014). The development of math-race stereotypes: "They say Chinese people are best at math." Journal of Research on Adolescence, 25(4), 630-37. doi: $10.1111 /$ jora.12151

Goleman, D. (1995). Emotional intelligence: Why it can matter more than IQ. New York, NY: Random House.

Gutiérrez, K. D., \& Rogoff, B. (2003). Cultural ways of learning: Individual traits or repertoires of practice. Educational Researcher, 32(5), 19-25. doi:10.3102/0013189X032005019

Hill, M. L. (2018). “Thank You, Black Twitter": State violence, digital counterpublics and pedagogies of resistance. Urban Education, 53(2), 286-302. doi:10.1177/0042085917747124

Johnson, W., Pate, D., \& Givens, J. (2010). Big boys don't cry, Black boys don't feel: The intersection of shame and worry on community violence and the social construction of masculinity among urban African American males - The case of Derrion Albert. In C. Edley, Jr., \& J. Ruiz de Velasco (Eds.), Changing places: How communities will improve the health of boys of color (pp. 462-492). Berkeley, CA: University of California Press.

Nasir, N. S. (2012). Racialized identities: Race and achievement among African American youth. Stanford, CA: Stanford University Press.

Nasir, N., Snyder, C., Shah, N., \& Ross, K. M. (2012). Racial storylines and implications for learning. Human Development, 55(5-6), 285-301. doi:10.1159/000345318

Rogoff, B. (2003). The cultural nature of human development. New York, NY: Oxford University.

Ross, K. M. (2016). Black girls speak: Struggling, reimagining, and becoming in schools (Unpublished doctoral dissertation), University of California, Berkeley, CA.

Ross, K. M. (in press). Black space in education: (Anti)blackness in schools and the afterlife of segregation in Grant, CA. In M.J. Dumas \& A.N. Woodson (Eds.), The future is Black: Afropessimism, fugitivity and radical hope in education. London, UK: Routledge.

Steele, D., \& Cohn-Vargas, B. (2013). Identity safe classrooms: Places to belong and learn. Los Angeles, CA: Corwin.

Tartaglione, N. (2017, December 27). Barack Obama talks dangers of social media use with Prince Harry. Deadline. Retrieved from https://Deadline.com/2017/12/barack-obama-prince-harry-interview-social-media-dangers-bbc-meghan-markle-1202232782/. 